\title{
Differential Effects of Caffeine on Dopamine and Acetylcholine Transmission in Brain Areas of Drug-naive and Caffeine-pretreated Rats
}

\author{
Elio Acquas, Ph.D., Gianluigi Tanda, Ph.D., and Gaetano Di Chiara, M.D.
}

The effects of caffeine on extracellular dopamine and acetylcholine have been studied in freely moving rats implanted with concentric microdialysis probes in the nucleus accumbens shell and core and in the medial prefrontal cortex. Intravenous administration of caffeine $(0.25,0.5,1.0,2.5$ and $5.0 \mathrm{mg} / \mathrm{kg})$ dose-dependently increased dopamine and acetylcholine dialysate concentrations in the medial prefrontal cortex, while it did not affect dialysate dopamine in the shell and core of the nucleus accumbens. Intraperitoneal administration of caffeine $(1.5,3,10,30 \mathrm{mg} / \mathrm{kg})$ also failed to affect DA in the shell and core of the nucleus accumbens. Such effects were duplicated by intravenous administration of DPCPX, a selective antagonist of adenosine $A_{1}$ receptors, and of $\mathrm{SCH}$ 58261, an antagonist of $A_{2 a}$ receptors. The effect of caffeine on prefrontal dopamine and acetylcholine transmission was also studied in rats chronically administered with caffeine (25 $\mathrm{mg} / \mathrm{kg}$, twice a day for seven days). At the end of this treatment rats became tolerant to the locomotor stimulating effects of a dose of 1 and $2.5 \mathrm{mg} / \mathrm{kg}$ i.v. of caffeine; these doses, however, still increased dialysate acetylcholine but did not affect dopamine in the prefrontal cortex. Therefore, in rats made tolerant to the locomotor stimulant effects of caffeine, tolerance developed to the dopamine stimulant but not to the acetylcholine stimulant effect of caffeine in the prefrontal cortex. The lack of acute stimulation of dopamine release in the nucleus accumbens shell by caffeine is relevant to the issue of its addictive properties and of the role of DA in drug-and substance-addiction. On the other hand, the dissociation between tolerance to the locomotor effects of caffeine and stimulation of acetylcholine release in the prefrontal cortex suggests that this effect might be correlated to the arousing effects of caffeine as distinct from its locomotor stimulant properties.

[Neuropsychopharmacology 27:182-193, 2002]

(C) 2002 American College of Neuropsychopharmacology. Published by Elsevier Science Inc.
KEY WORDS: Acetylcholine; Caffeine; Dopamine; Microdialysis; Nucleus Accumbens; Prefrontal cortex

From the Department of Toxicology, University of Cagliari, and Centre for Neuropharmacology - CNR, Via Ospedale72, I-09124 Cagliari, Italy.

Address correspondence to: Prof. Gaetano Di Chiara, Department of Toxicology \& Centre for Neuropharmacology - CNR, University of Cagliari, Via Ospedale 72 - I-09124, Cagliari, Italy. Tel.: +39 70675 8666/8667, fax: +39 70675 8612/86, E-mail: diptoss@ tin.it

Received August 6, 2001; revised January 9, 2002; accepted January 16,2002

Online publication: 1/17/02 at www.acnp.org/citations/Npp 011702226.
Caffeine is the active psychostimulant ingredient of widely consumed beverages. Although the large consumption of caffeine-containing beverages could be taken as indicative of its reinforcing properties, no consistent self-administration of caffeine has been obtained in laboratory animals including rats and non-human primates (Garrett and Griffiths 1998; Griffiths and Mumford 1995; Nehlig 1999). On the other hand, although tolerance and physical dependence can develop in humans after prolonged intake of caffeine, this drug is currently not included in the list of drugs that fulfill DSM-IV criteria for addiction (APA 1994; Chou et al. 1985; Fredholm et al. 1999; Nehlig 1999; Svenningsson et al. 1999). 
Caffeine's central effects are known to be due to blockade of adenosine $A_{1}$ and $A_{2 A}$ receptors. These receptors are widely distributed through the brain (Dixon et al. 1996; Lee and Reddington 1986; Palmer and Stiles 1995), adenosine $A_{1}$ receptors being present mostly in cortical layers, hippocampus and striatum (Dixon et al. 1996; Palmer and Stiles 1995) and $A_{2 a}$ receptors being co-localized with DA receptors in the striatum (Dixon et al. 1996; Palmer and Stiles 1995).

Acetylcholine (ACh) might be involved in the stimulant properties of caffeine. Cholinergic nerve terminals in the prefrontal cortex, originating in the $\mathrm{Ch}_{1}-\mathrm{Ch}_{4}$ nuclei of the basal forebrain cholinergic complex (Mesulam et al. 1983; Schwaber et al. 1987) have been involved in arousal and attentional processes (Fibiger 1991; Sarter and Bruno 2000). Cortical ACh release is increased following presentation of novel, behaviorally relevant stimuli (Acquas et al. 1996; Moore et al. 1993) but also as a consequence of an attentional load during performance in a 5-choice serial reaction time task (Passetti et al. 2000).

Adenosine exerts a strong control over ascending ACh projections to the thalamus and cortex. Thus, cholinergic nuclei of the mesopontine tegmentum $\left(\mathrm{Ch}_{5}-\mathrm{Ch}_{6}\right.$ nuclei, according to the nomenclature of Mesulam et al. (1983)) are tonically inhibited by adenosine through an action onto $A_{1}$ receptors (Rainnie et al. 1994). Prolonged wakefulness is associated to enhanced adenosine concentrations in the basal forebrain (Porkka-Heiskanen et al. 1997) as a result of local brain metabolism; moreover, induction of SW sleep is associated to increased levels of adenosine in brain (Strecker et al. 2000). On this basis it has been suggested that adenosine is an endogenous sleep factor (Strecker et al. 2000) and modulates EEGarousal through ACh projections to the cortex (Portas et al. 1997; Rainnie et al. 1994; Strecker et al. 2000).

Dopamine (DA) transmission is thought to be involved in the psychostimulant properties of drugs of abuse. Thus, microdialysis studies have shown that a neurochemical property common to psychostimulant and reinforcing drugs is the ability of preferentially stimulating DA release in the shell subdivision of the nucleus accumbens (Cadoni and Di Chiara 1999, 2000; Di Chiara 1999; Pontieri et al. 1995, 1996; Tanda et al. 1997). Given the psychostimulant properties of caffeine, its debated reinforcing and addictive properties and the postulated involvement of $\mathrm{ACh}$ in its arousing effects, it was of interest to investigate the effects of caffeine on $\mathrm{DA}$ and ACh transmission.

With these premises we studied with microdialysis in freely-moving rats the effect of caffeine on extracellular DA and ACh levels in the shell and in the core of the NAc (Heimer et al. 1991; Heimer and Alheid 1991) and in the prefrontal cortex (PFCX). In order to investigate the relationship between the psychostimulant properties of caffeine, as estimated by its locomotor stimulant properties, the relationship between tolerance to caffeine's psychostimulant effects and changes in DA and ACh transmission was also studied. The effects of caffeine were compared with those of selective antagonists for adenosine $A_{1}$ or $A_{2 A}$ receptors. Caffeine was administered by two routes: intravenous, through subchronically implanted catheters, and intraperitoneal. The intravenous route was utilized in experiments involving monitoring DA and ACh in the PFCX so as to avoid manipulating the animals during drug-injection and to artifactually stimulate cortical DA and ACh transmission. The intraperitoneal route of administration was utilized, comparatively with the intravenous one, in experiments involving monitoring of DA in the NAc shell and core areas, where this manuever induces only minor changes in DA and ACh transmission. The intraperitoneal route was also utilized in order to allow comparison of the results with those of previous placepreference studies utilizing the same route (Patkina and Zvartau 1998; Bedginfield et al. 1998).

\section{EXPERIMENTAL PROCEDURE}

\section{Animals}

Male Sprague-Dawley rats (275-300 g) were housed in groups of two or three per cage for at least three days before use and were maintained on a 12:00/12:00 $\mathrm{h}$ light/dark cycle (lights on at 7:30 A.M.) with food and water available ad libitum. After surgery the rats were housed individually in plexiglas hemispherical bowls (50 $\mathrm{cm}$ of diameter) which also served as the experimental environment, where they recovered for 24-30 h prior to the microdialysis experiments. Experiments were carried out between 9:00 A.M. and 4:00 P.M. Animal care and experimental protocol were conducted in accordance with guidelines of national (D.L. 116, Suppl. G.U. 40, 18/2/1992 and circolare no. 8 G.U. 14/7/1994) and international (EEC council Directive 86/609, OJ L 358/1, Dec. 12, 1987) policies.

\section{Surgery and Microdialysis}

Rats were anesthetized with ketamine $\mathrm{HCl}$ (Ketalar, Parke Davis Spa, Italy) (100 mg/kg i.p.) and stereotaxically implanted with a vertical concentric microdialysis probe in the left medial prefrontal cortex, and in different subjects in their left nucleus accumbens shell and right nucleus accumbens core. The coordinates, measured from bregma, were $\mathrm{AP}=+3.6 \mathrm{~mm}, \mathrm{ML}=-0.7$, $\mathrm{DV}=-4.8 \mathrm{~mm}$ from dura, for the medial prefrontal cortex, and $\mathrm{AP}=+2.2 \mathrm{~mm}, \mathrm{ML}=-1.1, \mathrm{DV}=-8.0 \mathrm{~mm}$ from dura, and $\mathrm{AP}=+1.6 \mathrm{~mm}, \mathrm{ML}=+2.0, \mathrm{DV}=-7.8$ $\mathrm{mm}$, for the nucleus accumbens shell and core, respectively, according to (Paxinos and Watson 1998). For intravenous administration, under halothane anesthesia 
rats were implanted, in the same day, with a polyethylene catheter in the left femoral vein and tunneled subcutaneously to exit at the nape of the neck according to Crane and Porrino (1989). The membrane used was a polyacrylonitrile/sodium methallyl sulphonate copolymer (i.d. 0.22 mm, o.d. 0.31 mm; AN 69 filtral 8, Hospal Industrie, Italy). The membrane was covered with epoxy glue along its whole length except for $3 \mathrm{~mm}$ corresponding to the area of dialysis. The day of the experiment rats were connected to a microperfusion pump (BAS, Bee Hive, Lafayette, IN, USA) by polyethylene tubing (PE-50, Portex Ltd, Kent, UK)(INLET) connected to a $2.5 \mathrm{ml}$ glass syringe (Hamilton Company, USA) containing the perfusion solution. The perfusion flow was set at $1 \mu \mathrm{l} / \mathrm{min}$. The first three dialysate samples were discarded. Samples were collected every $10 \mathrm{~min}$ (10 $\mu \mathrm{l} /$ sample) into a $20 \mu \mathrm{l}$ sample loop (OUTLET) and subsequently injected in the high pressure liquid chromatograph (HPLC) injector valve operated manually. The perfusion solution contained $147 \mathrm{mM} \mathrm{NaCl}, 4 \mathrm{mM}$ $\mathrm{KCl}, 2.2 \mathrm{mM} \mathrm{CaCl}_{2}$, in twice distilled water. To achieve consistently detectable amounts of ACh in the dialysate, the reversible $\mathrm{ACh}$ esterase inhibitor neostigmine bromide $(0.01 \mu \mathrm{M})$ (Sigma, St. Louis, MO, USA) was added to the perfusion solution. ACh was assayed by HPLC-electrochemical detection (ECD) in conjunction with an enzyme reactor (Damsma et al. 1987). In the experiments in which DA was measured, the composition of the perfusion solution was identical but, in these experiments, the ACh esterase inhibitor was not included. ACh and choline were separated on a reverse phase Chromspher $\mathrm{C}_{18} 5 \mu \mathrm{m}$ (Merck, Darmstad, FRG) column $(75 \times 2.1 \mathrm{~mm})$ pretreated with lauryl sulfate. The mobile phase passed directly through the enzyme reactor $(10 \times 2.1 \mathrm{~mm})$ containing ACh esterase (ED 3.1.1.7; type VI-S - Sigma, St. Louis, MO, USA) and choline oxidase (EC 1.1.3.17; Sigma, St. Louis, MO, USA) covalently bound to glutaraldehyde-activated Lichrosorb 10- $\mathrm{NH}_{2}$ (Merck, Darmstad, FRG); ACh and choline were quantitatively converted into hydrogen peroxide which was detected electrochemically at a platinum working electrode set at $500 \mathrm{mV}$ versus an $\mathrm{Ag} / \mathrm{AgCl}$ reference electrode (LC-4B, BAS, Lafayette, IN, USA). The mobile phase was an aqueous potassium phosphate buffer (1.9 $\mathrm{mM} \mathrm{K} \mathrm{HPO}_{4}, 0.2 \mathrm{mM}$ tetramethyl ammonium hydroxide, $\mathrm{pH}=8$ ) delivered at a constant flow of $0.4 \mathrm{ml} / \mathrm{min}$ by an HPLC pump (Bischoff HPLC Pump Mod. 2200, Bischoff, FRG). The chromatograms were recorded on a chart recorder. The detection limit of the assay was 50 $\mathrm{fmol} / \mathrm{sample}$. Injections of an ACh standard (20 $\mu \mathrm{l}, 0.1$ $\mu \mathrm{M}$ ) were made every 60 to $90 \mathrm{~min}$ in order to monitor changes in electrode sensitivity and sample concentrations were corrected accordingly. DA was assayed by HPLC-ECD. The mobile phase was delivered by an HPLC pump (Pharmacia LKB, HPLC pump 2150) at the constant flow of $1.20 \mathrm{ml} / \mathrm{min}$ and consisted of $\mathrm{NaH}_{2} \mathrm{PO}_{4}$
(50 mM), $\mathrm{Na}_{2} \mathrm{HPO}_{4}(5 \mathrm{mM}), \mathrm{Na}_{2}$ EDTA $(0.1 \mathrm{mM})$, octanesulfonic acid (0.5 mM) (Eastman Kodak Co., NY), and methanol $15 \% \mathrm{v} / \mathrm{v}, \mathrm{pH}=5.5$. DA was separated by reverse phase liquid chromatography $(150 \times 4.6 \mathrm{~mm}$, Supelco $\left.5 \mu \mathrm{m} \mathrm{LC}_{18} \mathrm{DB}\right)$. The electrochemical detector (Coulochem II, ESA Inc., Bedford, MA, USA) was set as follows: oxidation electrode $+75 \mathrm{mV}$, reduction electrode $-125 \mathrm{mV}$. The sensitivity of the assay for DA was $2 \mathrm{fmol} / \mathrm{sample}$. The chromatograms were recorded on a chart recorder.

\section{Drugs}

Caffeine (RBI-Sigma, Natick, MA, USA), dissolved in saline was administered i.v. or intraperitoneally (during the chronic treatment at the dose of $25 \mathrm{mg} / \mathrm{kg}$ ) in a volume of $1 \mathrm{ml} / \mathrm{kg}$. SCH 58261 (Schering-Plough, Milan, Italy, (7-(2-phenylethyl)-5-amino-2-(2-furyl)-pyrazolo[4,3,e]-1,2,4-triazolo[1,5-c]-pyrimidine)) and DPCPX (8cyclopentyl-1,3-dipropylxanthine), RBI-Sigma, Natick, MA, USA) were suspended in saline with the addition of $0.3 \%$ TWEEN 80 in a volume of $1 \mathrm{ml} / \mathrm{kg}$.

\section{Statistics}

Values are expressed as changes percent with respect to baseline $(100 \%)$. Baseline was set as the average of the last six pretreatment samples (not differing more than 15\%). Basal DA and ACh output were, respectively: NAc Shell: $56.7 \pm 9.2 \mathrm{fmol} / \mathrm{min}$. \pm S.E.M. $(\mathrm{n}=18$ ) (caffeine i.v.); NAc Shell: $62.2 \pm 8.4 \mathrm{fmol} / \mathrm{min} . \pm$ S.E.M. $(\mathrm{n}=16)$ (caffeine i.p.); NAc Core: $59.5 \pm 9.6 \mathrm{fmol} / \mathrm{min}$. \pm S.E.M. $(\mathrm{n}=18)$ (caffeine i.v.); NAc Core: $61.9 \pm 10.1 \mathrm{fmol} / \mathrm{min} . \pm$ S.E.M. $(n=8)$ (caffeine i.p.); PFCx - (DA, chronic saline and naive): $10.6 \pm 1.9 \mathrm{fmol} / \mathrm{min}$. \pm S.E.M. $(\mathrm{n}=74)$; PFCx - (DA, chronic caffeine): $10.0 \pm 1.1 \mathrm{fmol} / \mathrm{min} . \pm$ S.E.M. $(\mathrm{n}=12)$; PFCx - (ACh, chronic saline and naive): $19 \pm 1 \mathrm{fmol} / \mathrm{min} . \pm$ S.E.M. $(\mathrm{n}=77)$ and PFCx $-(\mathrm{ACh}$, chronic caffeine): $17 \pm 2.11 \mathrm{fmol} / \mathrm{min}$. \pm S.E.M. $(\mathrm{n}=13)$. One-way and two-way analyses of variance (ANOVAs), with time as the repeated measure, were used to analyze the treatment effects. Tukey's post-hoc analyses were applied for multiple comparisons, with the statistical significance set at $p<.05$.

\section{RESULTS}

\section{Effect of Intravenous Caffeine on Dialysate Dopamine in the Prefrontal Cortex, Nucleus Accumbens Shell and Core}

Figure 1 shows the effect of caffeine, administered at doses of $0.25,0.5,1.0,2.5$ and $5.0 \mathrm{mg} / \mathrm{kg}$ i.v. on dialysate DA in the PFCx and nucleus accumbens, shell and core. Caffeine significantly modified DA in the PFCx at all doses except the lowest $(0.25 \mathrm{mg} / \mathrm{kg})$, but not in the 

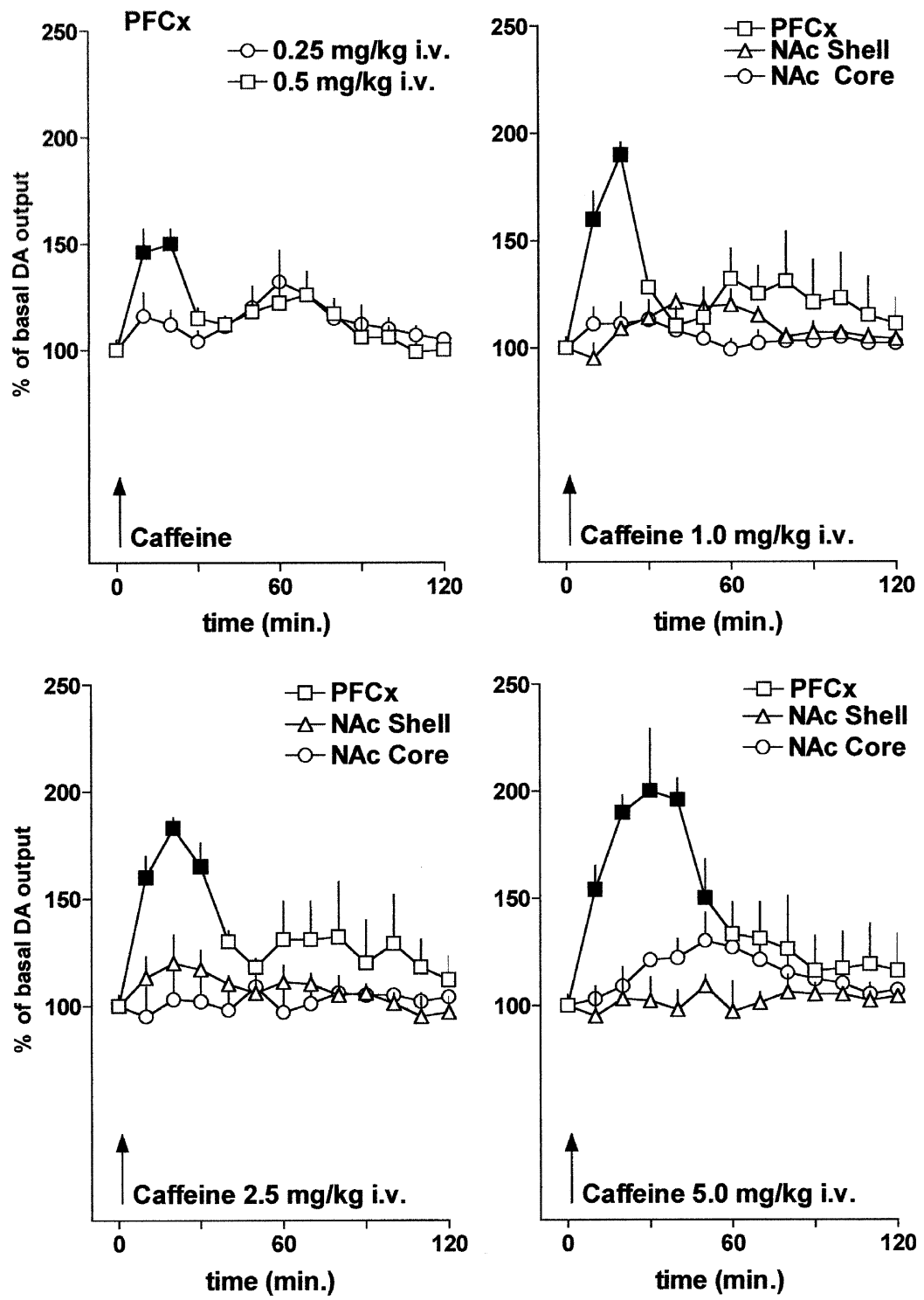

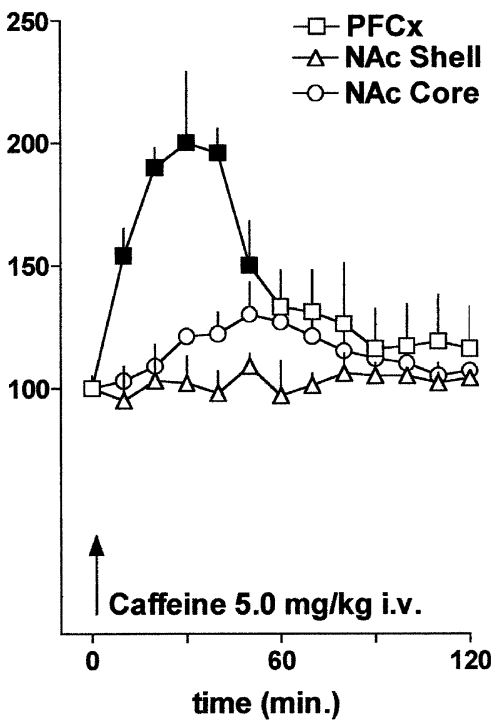

Figure 1. Effect of intravenous administration of caffeine $0.25 \mathrm{mg} / \mathrm{kg}(\mathrm{n}=4), 0.5 \mathrm{mg} / \mathrm{kg}$ (PFCX n = 6), $1.0 \mathrm{mg} / \mathrm{kg}$ (PFCX $\mathrm{n}=4), 2.5$ $\mathrm{mg} / \mathrm{kg}(\mathrm{PFCX} \mathrm{n}=5)$ and $5.0 \mathrm{mg} / \mathrm{kg}(\mathrm{PFCX}$ $\mathrm{n}=3$ ) and of caffeine $1.0 \mathrm{mg} / \mathrm{kg}$ (NAc shell $\mathrm{n}=4$; NAc core $\mathrm{n}=4), 2.5 \mathrm{mg} / \mathrm{kg}$ (NAc shell $\mathrm{n}=4$; NAc core $\mathrm{n}=3$ ) and $5.0 \mathrm{mg} / \mathrm{kg}$ (NAc shell $n=3$; NAc core $n=3$ ) on nucleus accumbens and prefrontal cortical DA release. Statistical analysis: PFCx: caffeine $0.25 \mathrm{mg} / \mathrm{kg}$ : $\left(\mathrm{F}_{12,36}=1.78, \mathrm{~ns}\right) ; 0.5 \mathrm{mg} / \mathrm{kg}:\left(\mathrm{F}_{12,84}=4.14, p<\right.$ $.005 ; p<.05$ post hoc); $1.0 \mathrm{mg} / \mathrm{kg}:\left(\mathrm{F}_{12,60}=\right.$ $4.56, p<.0003 ; p<.05$ post hoc); $2.5 \mathrm{mg} / \mathrm{kg}$ : $\left(\mathrm{F}_{12,48}=3.04, p<.002 ; p<.05\right.$ post hoc $)$ and $5.0 \mathrm{mg} / \mathrm{kg}:\left(\mathrm{F}_{12,24}=4.65, p<.0006\right.$ and $p<$ .05 post hoc). NAc Shell: caffeine $1.0 \mathrm{mg} / \mathrm{kg}$ : $\left(\mathrm{F}_{6,6}=3.73, \mathrm{~ns}\right) ; 2.5 \mathrm{mg} / \mathrm{kg}:\left(\mathrm{F}_{6,18}=1.38, \mathrm{~ns}\right)$ and $5.0 \mathrm{mg} / \mathrm{kg}$ : $\left(\mathrm{F}_{6,12}=0.23, \mathrm{~ns}\right)$; NAc Core: $1.0 \mathrm{mg} / \mathrm{kg}:\left(\mathrm{F}_{6,6}=2.87, \mathrm{~ns}\right) ; 2.5 \mathrm{mg} / \mathrm{kg}:\left(\mathrm{F}_{6,12}=\right.$ $0.3, \mathrm{~ns})$ and $5.0 \mathrm{mg} / \mathrm{kg}:\left(\mathrm{F}_{6,12}=0.23, \mathrm{~ns}\right)$. Values are expressed as percentage of baseline. Vertical bars represent S.E.M. Filled symbols indicate the sample points significantly different from baseline $(p<.05$, post hoc test).
NAc shell and core (see legend to Figure 1 for statistical analysis). Two-way ANOVA showed that the effects of caffeine on PFCx DA were dose- $\left(\mathrm{F}_{4,215}=10.16, p<.001\right)$ and time-dependent $\left(\mathrm{F}_{9,210}=9.61, p<.001\right)$ with a significant dose $\mathrm{X}$ time interaction $\left(\mathrm{F}_{36,170}=1.72, p<.02\right)$. Tukey's post hoc test revealed that the changes of DA output after caffeine $5.0 \mathrm{mg} / \mathrm{kg}$ were significantly larger $(p<.05)$ than those after caffeine $0.25,0.5$ and $1.0 \mathrm{mg} / \mathrm{kg}$. DA peaked around 10,20 , or 30 min depending on the dose and was back to basal around $50 \mathrm{~min}$ after drug administration. A late (60 min.) increase of dialysate DA in the PFCX was observed after caffeine $1 \mathrm{mg} / \mathrm{kg}$.

\section{Effect of Intraperitoneal Caffeine on Dialysate Dopamine in Nucleus Accumbens Shell and Core}

The effect of the intraperitoneal administration of caffeine was studied on DA transmission in the NAc shell $(1.5,3.0$,
10 and $30 \mathrm{mg} / \mathrm{kg}$ ) and core (10 and $30 \mathrm{mg} / \mathrm{kg})$. As shown in Figure 2, caffeine failed to significantly affect DA transmission at all doses tested (see legend to Figure 2 for statistical analysis). Two-way ANOVA showed that the effects of caffeine on DA were neither dose- $\left(\mathrm{F}_{3,108}=2.04\right.$, NS) nor time-dependent $\left(\mathrm{F}_{6,105}=2.85, \mathrm{NS}\right)$ in the shell and in the core: (dose, $\mathrm{F}_{1,40}=0.5, \mathrm{NS}$; time, $\mathrm{F}_{6,35}=1.28, \mathrm{NS}$ ).

\section{Effects of Caffeine on Dialysate Acetylcholine in the Prefrontal Cortex}

As shown in Figure 3, intravenous administration of caffeine significantly modified dialysate ACh in the PFCx at all doses tested (see legend to Figure 3 for statistical analysis). Two-way ANOVA revealed a main effect of dose $\left(\mathrm{F}_{3,18}=4,83, p<.01\right)$; Tukey's post hoc test revealed a significant difference between the effect of $0.25 \mathrm{mg} / \mathrm{kg}$ as compared with that of $2.5 \mathrm{mg} / \mathrm{kg}(p<.05)$. 

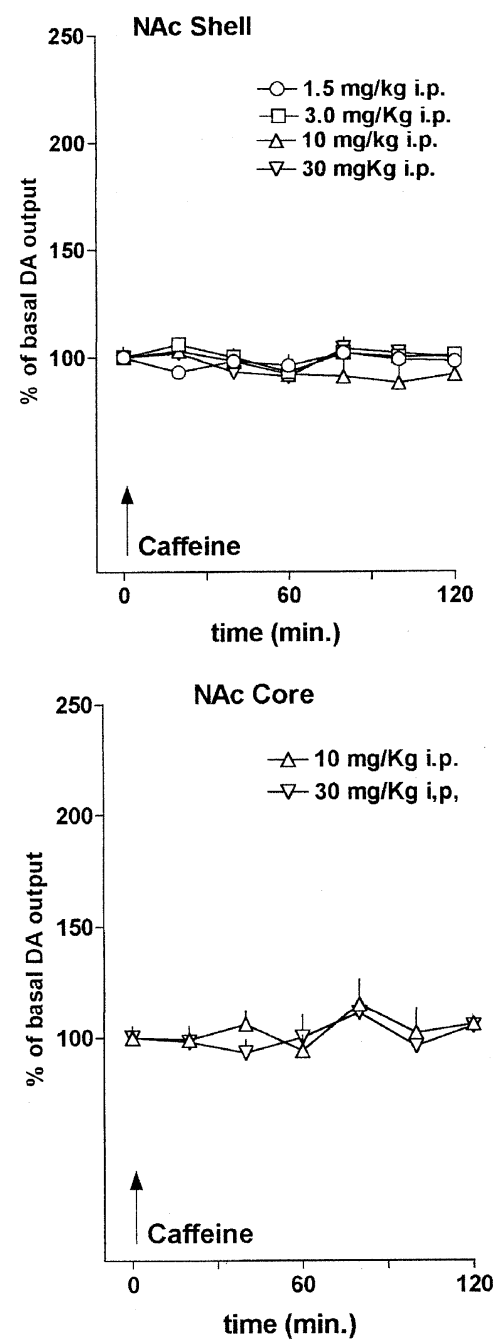

Figure 2. Effect of intraperitoneal administration of caffeine $1.5 \mathrm{mg} / \mathrm{kg}, 3.0 \mathrm{mg} / \mathrm{kg}, 10 \mathrm{mg} / \mathrm{kg}$, and $30 \mathrm{mg} / \mathrm{kg}$ on nucleus accumbens DA release (NAc Shell, $\mathrm{n}=16$; NAc core, $\mathrm{n}=8$ ). Statistical Analysis: NAc Shell: caffeine $1.5 \mathrm{mg} / \mathrm{kg}$ : $\left(\mathrm{F}_{6,21}=\right.$ $1.23, \mathrm{~ns}) ; 3.0 \mathrm{mg} / \mathrm{kg}:\left(\mathrm{F}_{6,21}=2.11, \mathrm{~ns}\right), 10 \mathrm{mg} / \mathrm{kg}:\left(\mathrm{F}_{6,21}=1,03\right.$, $\mathrm{ns})$ and $30 \mathrm{mg} / \mathrm{kg}\left(\mathrm{F}_{6,21}=1.86, \mathrm{~ns}\right)$ (1-way ANOVA); NAc Core: $10 \mathrm{mg} / \mathrm{kg}:\left(\mathrm{F}_{6,14}=0.79, \mathrm{~ns}\right)$ and $30 \mathrm{mg} / \mathrm{kg}:\left(\mathrm{F}_{6,14}=\right.$ 0.849 , ns) (1-way ANOVA). Values are expressed as percentage of baseline. Vertical bars represent S.E.M.

\section{Effect of DPCPX on Dialysate Dopamine in the Prefrontal Cortex, Nucleus Accumbens Shell and Core}

As shown in Figure 4, the adenosine $\mathrm{A}_{1}$ antagonist, DPCPX, significantly modified dialysate DA in the PFCx at all doses tested (see legend to Figure 4 for statistical analysis). Two-way ANOVA showed these effect to be dose- $\left(\mathrm{F}_{3,194}=18.083, p<.001\right)$ and timedependent $\left(\mathrm{F}_{9,190}=14.96, p<.001\right)$ with a significant dose $\mathrm{X}$ time interaction $\left(\mathrm{F}_{36,149}=4.49, p<.001\right)$.

Figure 4 also shows that DPCPX, at the dose of 0.5 $\mathrm{mg} / \mathrm{kg}$ i.v., did not significantly modify dialysate DA
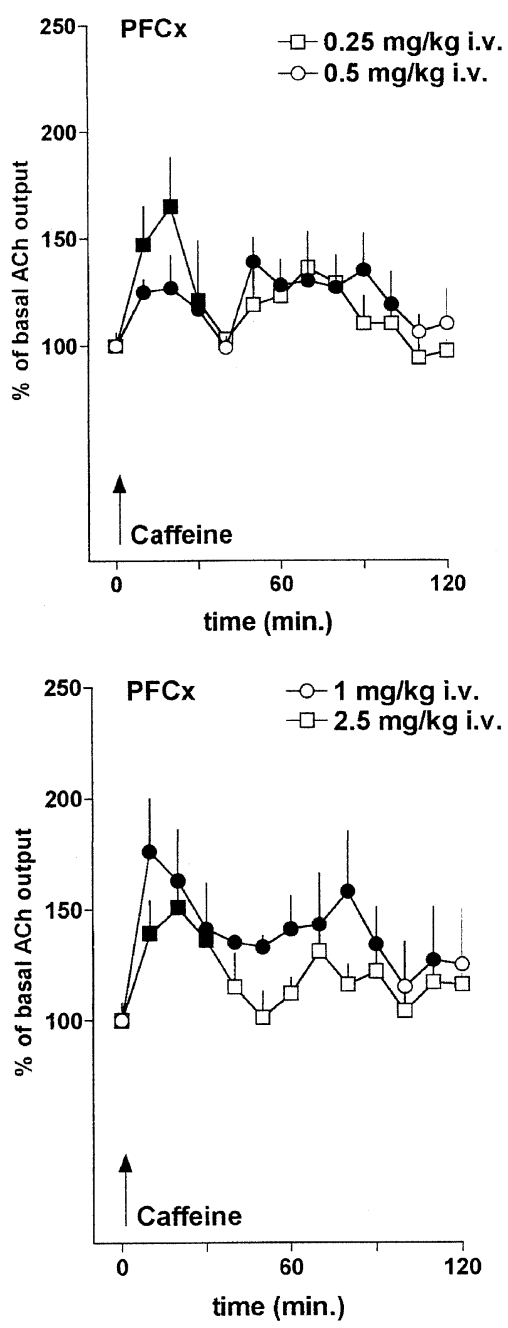

Figure 3. Effect of intravenous administration of caffeine $0.25 \mathrm{mg} / \mathrm{kg}(\mathrm{n}=6)$ and $0.5 \mathrm{mg} / \mathrm{kg}(\mathrm{n}=5), 1.0 \mathrm{mg} / \mathrm{kg}(\mathrm{n}=$ $5)$ and $2.5 \mathrm{mg} / \mathrm{kg}(\mathrm{n}=6)$ on prefrontal cortical ACh release. Statistical analysis: $\left(0.25 \mathrm{mg} / \mathrm{kg}: \mathrm{F}_{11,55}=2.22, p<.03 ; p<\right.$ .05 post hoc $; 0.5 \mathrm{mg} / \mathrm{kg}: \mathrm{F}_{14,48}=2.3, p<.025 ; p<.05$ post hoc; $1.0 \mathrm{mg} / \mathrm{kg}: \mathrm{F}_{12,48}=4.04, p<.0001 ; p<.05$ post hoc $; 2.5$ $\mathrm{mg} / \mathrm{kg}: \mathrm{F}_{12,60}=3.88, p<.0001 ; p<.05$ post hoc). Values are expressed as percentage of baseline. Vertical bars represent S.E.M. Filled symbols indicate the sample points significantly different from baseline ( $p<.05$, post hoc test).

in the NAc shell $\left(\mathrm{F}_{12,12}=0.82, \mathrm{NS}\right)$ and core $\left(\mathrm{F}_{12,12}=\right.$ $0.94, \mathrm{NS})$.

\section{Effect of DPCPX Dialysate Acetylcholine in the Prefrontal Cortex}

Figure 5 shows the effects of DPCPX at the doses of $0.0625,0.125$ and $0.25 \mathrm{mg} / \mathrm{kg}$ i.v. on dialysate ACh in the PFCx. DPCPX significantly modified ACh release (1-way ANOVA) at all doses tested (see legend to Figure 5 for statistical analysis). Two-way ANOVA also showed these effects to be dose- $\left(\mathrm{F}_{2,167}=16.38 ; p<.0001\right)$ and 

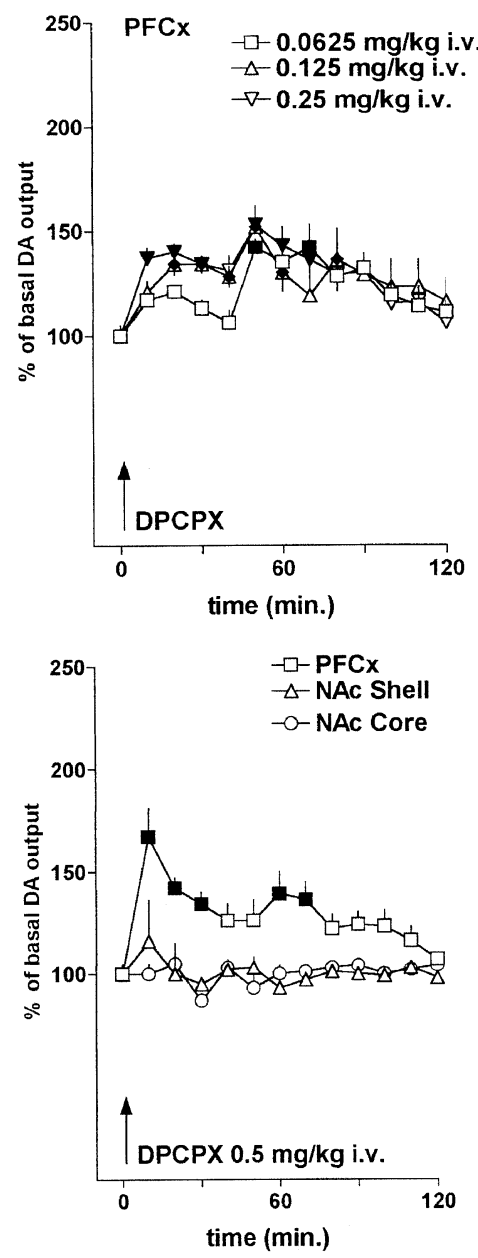

Figure 4. Effect of intravenous administration of DPCPX $0.0625 \mathrm{mg} / \mathrm{kg}(\mathrm{n}=4), 0.125 \mathrm{mg} / \mathrm{kg}(\mathrm{n}=5), 0.25 \mathrm{mg} / \mathrm{kg}(\mathrm{n}=$ 5), $0.5 \mathrm{mg} / \mathrm{kg}$ (PFCx $\mathrm{n}=5$, NAc shell $\mathrm{n}=4$, and NAc core $\mathrm{n}=4$ ) on nucleus accumbens and prefrontal cortical DA release. Statistical Analysis: $0.0625 \mathrm{mg} / \mathrm{kg}$ i.v., $\left(\mathrm{F}_{12,24}=6.44\right.$, $p<.00005$, and $p<.05$, post hoc test), $0.125 \mathrm{mg} / \mathrm{kg}$ i.v., $\left(\mathrm{F}_{12,72}=2.30, p<.015\right.$ and $p<.05$, post hoc test $), 0.25 \mathrm{mg} / \mathrm{kg}$ i.v. $\left(\mathrm{F}_{12,48}=1.87, p<.06\right.$ and $p<.05$, post hoc test $), 0.5 \mathrm{mg} /$ kg i.v. $\left(\mathrm{F}_{6,24}=5.56, p<.0009\right.$ and $p<.05$, post hoc test). Values are expressed as percentage of baseline. Vertical bars represent S.E.M. Filled symbols indicate the sample points significantly different from baseline ( $p<.05$, post hoc test).

time-dependent $\left(\mathrm{F}_{9,169}=7.57, p<.0001\right)$. Post hoc analysis showed that the increases after the dose of DPCPX $0.25 \mathrm{mg} / \mathrm{kg}$ were significantly larger than those after DPCPX 0.0625 and $0.125 \mathrm{mg} / \mathrm{kg}(p<.05)$.

\section{Effect of SCH 58261 on Dialysate Dopamine in the Prefrontal Cortex, Nucleus Accumbens Shell and Core}

As shown in Figure 6, the intravenous administration of the specific $\mathrm{A}_{2 \mathrm{~A}}$ antagonist, $\mathrm{SCH} 58261$ significantly changed dialysate DA in the PFCx at all doses tested
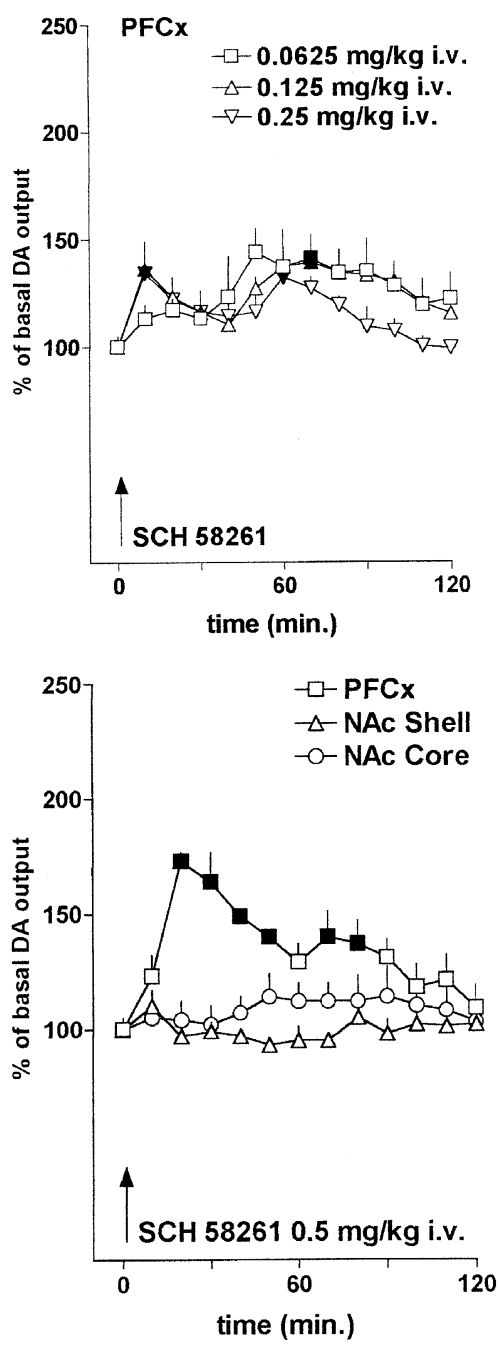

Figure 5. Effect of intravenous administration of $\mathrm{SCH}$ $582610.0625 \mathrm{mg} / \mathrm{kg}(\mathrm{n}=3), 0.125 \mathrm{mg} / \mathrm{kg}(\mathrm{n}=4), 0.25 \mathrm{mg} /$ $\mathrm{kg}(\mathrm{n}=4), 0.5 \mathrm{mg} / \mathrm{kg}$ (PFCx $\mathrm{n}=5$, NAc shell $\mathrm{n}=3$, and NAc core $n=4)$ and $1.0 \mathrm{mg} / \mathrm{kg}(\mathrm{PFCx} \mathrm{n}=5)$ on prefrontal cortical and nucleus accumbens DA release. Statistical analysis: $0.0625 \mathrm{mg} / \mathrm{kg}\left(\mathrm{F}_{12,72}=4.7, p<.009\right.$, and $p<.05$, post hoc test), $0.125 \mathrm{mg} / \mathrm{kg}\left(\mathrm{F}_{12,60}=4.23, p<.014\right.$, and $p<.05$, post hoc $)$ and $0.25 \mathrm{mg} / \mathrm{kg}\left(\mathrm{F}_{12,36}=7.3, p<.0001\right.$, and $p<.05$, post hoc analysis). Values are expressed as percentage of baseline. Vertical bars represent S.E.M. Filled symbols indicate the sample points significantly different from baseline $(p<.05$, post hoc test).

(see legend to Figure 6 for statistical analysis). These increases were also dose- $(\mathrm{F} 3,205=12.008, p<.001)$ and time-dependent $\left(\mathrm{F}_{9,200}=9.876, p<.001\right)$, with a significant dose $\mathrm{X}$ time interaction $\left(\mathrm{F}_{36,160}=2.610, p<.001\right)$. Tukey's post hoc analysis revealed that the increases of DA output after SCH $582610.5 \mathrm{mg} / \mathrm{kg}$ was significantly larger than those after SCH $582610.0625,0.125$ and $0.25 \mathrm{mg} / \mathrm{kg}(p<.05)$. DA peaked at 10-20 min depending on the dose. As shown in Figure 6, SCH 58261, at the dose of $0.5 \mathrm{mg} / \mathrm{kg}$ i.v., failed to significantly 


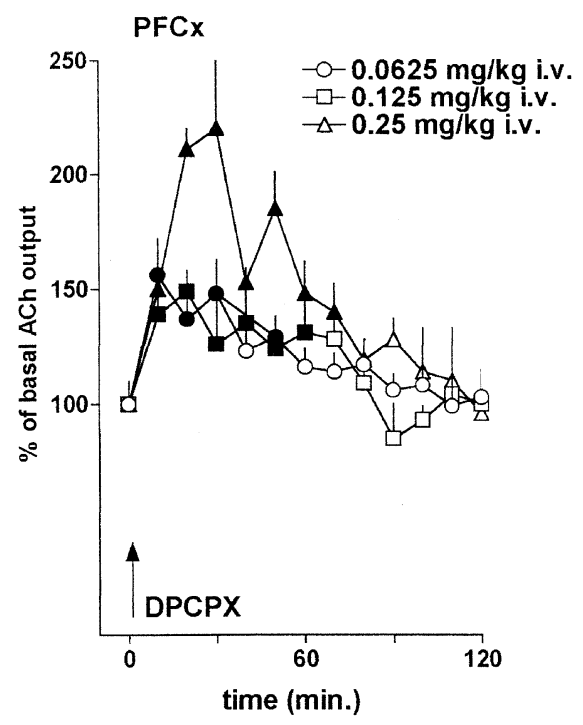

Figure 6. Effect of intravenous administration of DPCPX $0.0625 \mathrm{mg} / \mathrm{kg}(\mathrm{n}=7), 0.125 \mathrm{mg} / \mathrm{kg}(\mathrm{n}=6)$ and $0.25 \mathrm{mg} / \mathrm{kg}$ $(\mathrm{n}=4)$ on prefrontal cortical ACh release. Values are expressed as percentage of baseline. Statistical analysis: 0.0625 $\mathrm{mg} / \mathrm{kg}:\left(\mathrm{F}_{9,18}=2.47, p<.048\right.$, and $p<.05$, post hoc analysis); $0.125 \mathrm{mg} / \mathrm{kg}:\left(\mathrm{F}_{12,36}=2.18, p<.035\right.$, and $p<.05$, post hoc); $0.25 \mathrm{mg} / \mathrm{kg}$ : $\left(\mathrm{F}_{12,36}=3.00, p<.005\right.$, and $p<.05$, post hoc analysis); $0.5 \mathrm{mg} / \mathrm{kg}$ : $\left(\mathrm{F}_{12,60}=9.61, p<.00001\right.$, and $p<$ .05 , post hoc analysis); and $1.0 \mathrm{mg} / \mathrm{kg}:\left(\mathrm{F}_{12,60}=9.64, p<\right.$ .00001 , and $p<.05$, post hoc analysis). Vertical bars represent S.E.M. Filled symbols indicate the sample points significantly different from baseline ( $p<.05$, post-hoc analysis).

modify dialysate DA in the NAc shell $\left(\mathrm{F}_{10,20}=0.95, \mathrm{NS}\right)$ and core $\left(\mathrm{F}_{10,20}=1.21, \mathrm{NS}\right)$.

\section{Effect of SCH 58261 on Dialysate Acetylcholine in the Prefrontal Cortex}

As shown in Figure 7, SCH 58261 significantly changed dialysate $\mathrm{ACh}$ at all doses tested (see legend to Figure 7 for statistical analysis). SCH 58261 modified ACh release in the PFCx in a dose- $\left(\mathrm{F}_{4,21}=514.82, p<.0001\right)$ and time-dependent fashion $\left(\mathrm{F}_{11,231}=5.28, p<.00001\right)$ and with a significant dose $\mathrm{X}$ time interaction $\left(\mathrm{F}_{44,231}=\right.$ 2.04, $p<.0004$ ). As shown in Figure 7, the effect of the intermediate dose of $0.25 \mathrm{mg} / \mathrm{kg}$ i.v. of SCH 58261 were significantly larger than those of the lower doses 0.0625 and $0.125 \mathrm{mg} / \mathrm{kg}$ as well as the higher doses 0.5 and 1 $\mathrm{mg} / \mathrm{kg}$ i.v. $(p<.05$, post hoc test), indicative of a bellshaped dose effect relationship.

\section{Effects of Chronic Treatment with Caffeine on Caffeine-induced Changes in Prefrontal Cortical Dopamine and Acetylcholine Release}

In order to study the effects of repeated administration of caffeine on the neurochemical responses to acute caf-
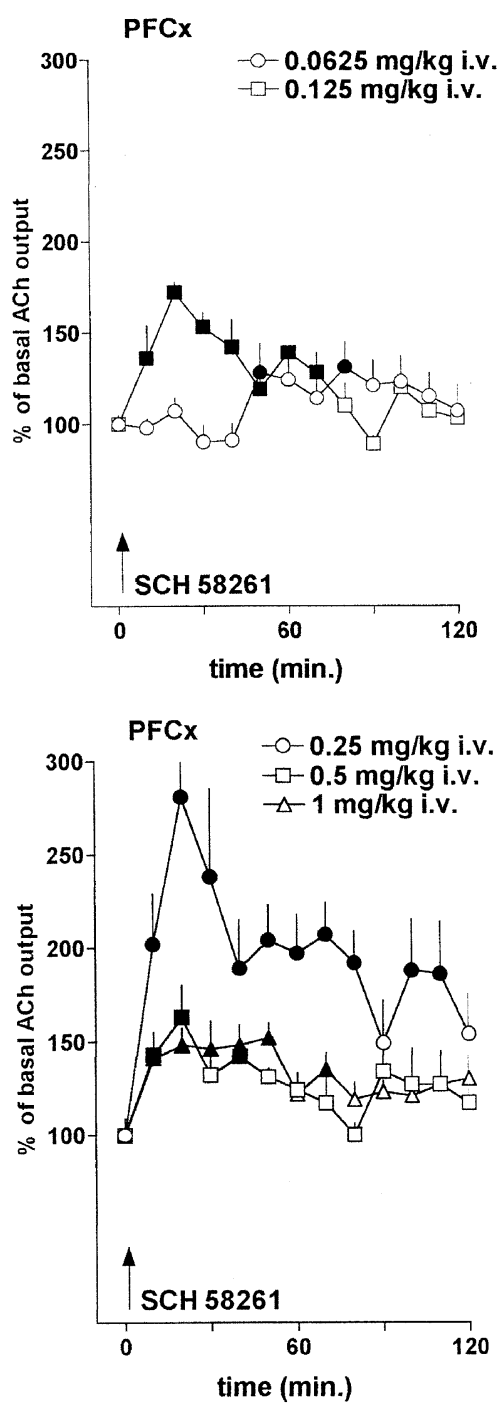

Figure 7. Effect of intravenous administration of $\mathrm{SCH}$ $582610.0625 \mathrm{mg} / \mathrm{kg}(\mathrm{n}=7), 0.125 \mathrm{mg} / \mathrm{kg}(\mathrm{n}=4), 0.25 \mathrm{mg} /$ $\mathrm{kg}(\mathrm{n}=5), 0.5 \mathrm{mg} / \mathrm{kg}(\mathrm{n}=5)$ and $1 \mathrm{mg} / \mathrm{kg}(\mathrm{n}=5)$ on prefrontal cortical ACh release. Statistical analysis: $0.0625 \mathrm{mg} /$ $\mathrm{kg}\left(\mathrm{F}_{12,72}=2.14, p<.025\right.$, and $p<.05$, post hoc $), 0.125 \mathrm{mg} /$ $\mathrm{kg}\left(\mathrm{F}_{12,36}=6.16, p<.001\right.$, and $p<.05$, post hoc $), 0.25 \mathrm{mg} / \mathrm{kg}$ $\left(\mathrm{F}_{12,48}=3.8, p<.0001\right.$, and $p<.05$, post hoc $), 0.5 \mathrm{mg} / \mathrm{kg}$ $\left(\mathrm{F}_{12,48}=2.17, p<.03\right.$, and $p<.05$, post hoc $)$ and $1.0 \mathrm{mg} /$ $\mathrm{kg}\left(\mathrm{F}_{12,48}=2.19, p<.03\right.$, and $p<.05$, post hoc $)$. Values are expressed as percentage of baseline. Vertical bars represent S.E.M. Filled symbols indicate the sample points significantly different from baseline ( $p<.05$, post-hoc analysis).

feine, caffeine was administered to rats for seven days (twice a day, $25 \mathrm{mg} / \mathrm{kg}$ i.p.). On the eighth day rats were implanted with a catheter in their right femoral vein and with a microdialysis probe in the medial prefrontal cortex. Figure 8 (top left) shows that caffeine (1.0 $\mathrm{mg} / \mathrm{kg}$ i.v.) failed to significantly affect dialysate DA in the PFCx $\left(\mathrm{F}_{12,60}=0.80, \mathrm{NS}\right)$ of rats chronically exposed to caffeine; 2-way ANOVA showed a significant effect of treatment $\left(\mathrm{F}_{1,122}=21.16, p<.001\right)$ and time $\left(\mathrm{F}_{12,111}=\right.$ 

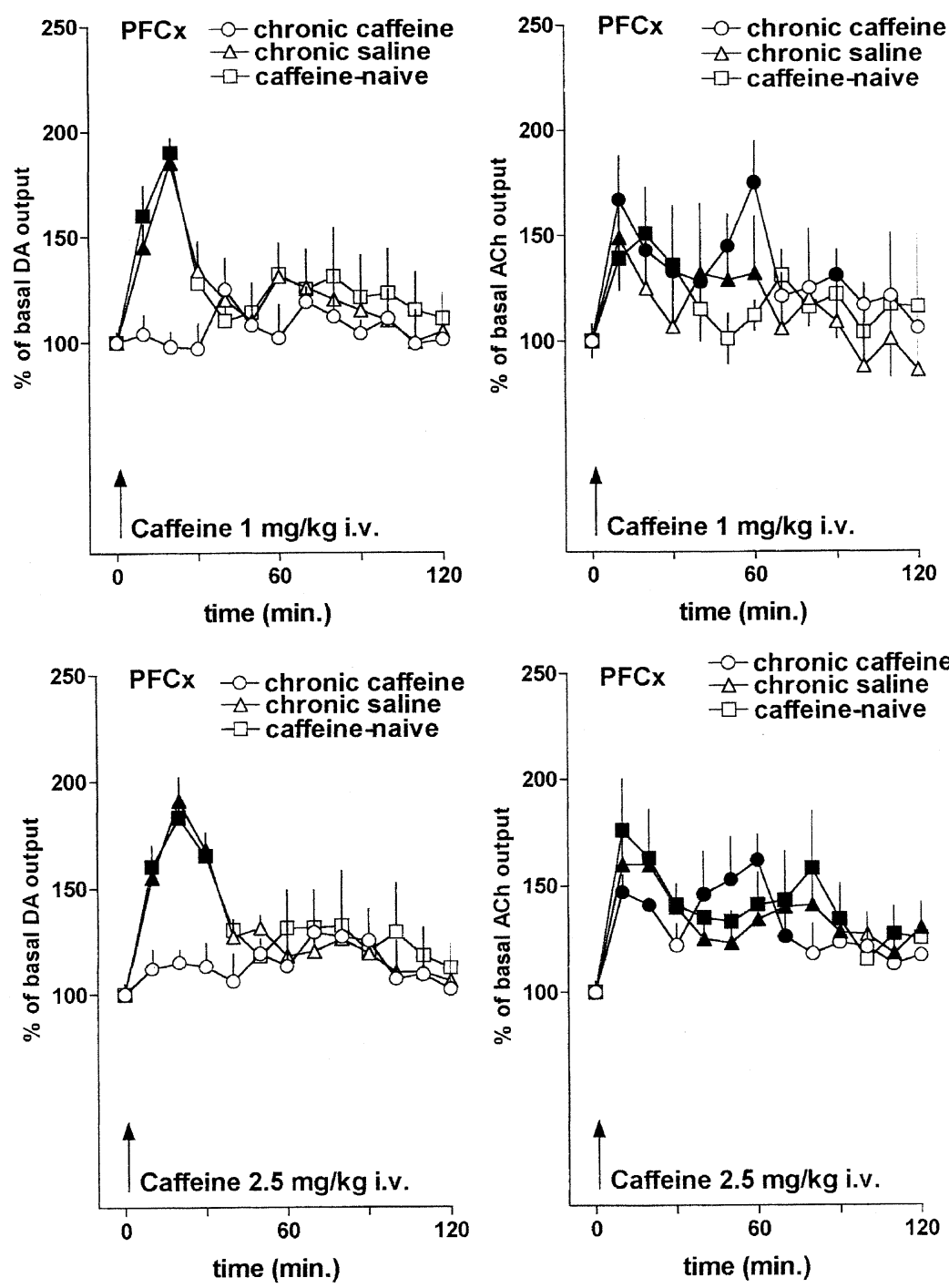

Figure 8. Top left: Effect of intravenous administration of caffeine $1.0 \mathrm{mg} / \mathrm{kg}$ to rats chronically treated with saline $(n=5)$ or caffeine $(n=6)$ on prefrontal cortical DA release. Data of the caffeine-naive group, from Figure 1 , are shown here for comparison. Bottom left: Effect of intravenous administration of caffeine $2.5 \mathrm{mg} / \mathrm{kg}$ to rats chronically treated with saline $(n=7)$ or caffeine $(n=6)$ on prefrontal cortical DA release. Data of the caffeine-naive group, from Figure 1, are shown here for comparison.

Top right: Effect of intravenous administration of caffeine $1.0 \mathrm{mg} / \mathrm{kg}$ to rats chronically treated with saline $(n=4)$ or caffeine $(n=7)$ on prefrontal cortical ACh release. Data of the caffeine-naive group, from Figure 3, are shown here for comparison. Bottom right: Effect of intravenous administration of caffeine $2.5 \mathrm{mg} / \mathrm{kg}$ to rats chronically treated with saline $(n=8)$ or caffeine $(n=5)$ on prefrontal cortical ACh release. Data of the caffeine-naive group, from Figure 3, are shown here for comparison. Values are expressed as percentage of baseline. Vertical bars represent S.E.M. Filled symbols indicate the sample points significantly different from baseline ( $p<.05$, post-hoc analysis).
$1.34, p<.02)$ and a significant treatment $X$ time interaction $\left(\mathrm{F}_{12,98}=2.62, p<.005\right)$. Post hoc analysis revealed significant differences within the first 30 minutes after caffeine administration between the effect on chroniccaffeine and that on chronic-saline treated rats. Similarly, the administration of caffeine at the dose of 2.5 $\mathrm{mg} / \mathrm{kg}$ i.v. to rats chronically exposed to caffeine (Figure 8 , bottom left), failed to stimulate DA release in the medial PFCx $\left(\mathrm{F}_{12,72}=1.78, \mathrm{NS}\right) ; 2$-way ANOVA of the effect of caffeine in chronic-saline versus chronic-caffeine treated rats, yielded a significant effect of treatment $\left(\mathrm{F}_{1,150}=20.11, p<.001\right)$, time $\left(\mathrm{F}_{12,130}=2.34, p<\right.$ $.005)$ and a significant treatment $X$ time interaction $\left(\mathrm{F}_{12,127}=2.08, p<.05\right)$.

Figure 8 (right) also shows the effects of $1.0 \mathrm{mg} / \mathrm{kg}$ i.v. of caffeine in dialysate $\mathrm{ACh}$ in rats chronically exposed to caffeine or saline. Caffeine significantly modified $\mathrm{ACh}$ in the PFCx of caffeine pre-exposed rats $\left(\mathrm{F}_{12,72}=\right.$ $2.85, p<.002$, and $p<.05$, post hoc). Two-way ANOVA showed a significant effect of time $\left(\mathrm{F}_{12,108}=3.6, p<\right.$
$.0001)$, but not a significant effect of treatment $\left(\mathrm{F}_{1,9}=\right.$ $0.5, \mathrm{NS})$ or treatment $\mathrm{X}$ time interaction $\left(\mathrm{F}_{12,108}=0.37\right.$, NS). Similar results were obtained also when caffeine was administered at the dose of $2.5 \mathrm{mg} / \mathrm{kg}$ i.v. (Figure 8 , bottom right). At this dose caffeine significantly modified dialysate $\mathrm{ACh}$ in the PFCx of rats chronically treated with caffeine $\left(\mathrm{F}_{12,48}=2.95, p<.003\right.$, and $p<.05$, post hoc); 2-way ANOVA showed a significant effect of time $\left(\mathrm{F}_{12,132}=4.3, p<.00001\right)$, but not of treatment $\left(\mathrm{F}_{1,11}\right.$ $=0.05, \mathrm{NS})$ or treatment $\mathrm{X}$ time interaction $\left(\mathrm{F}_{12,132}=\right.$ $1.56, \mathrm{~ns})$.

\section{Behavioral Effects of Caffeine, DPCPX, and SCH 58261}

As shown in Figure 9, the administration of caffeine (1.0 and $2.5 \mathrm{mg} / \mathrm{kg}$ i.v.) evoked a dose-dependent behavioral activation described by four categories: (1) Grooming; (2) Sniffing, (3) Locomotion, and (4) Resting (in this latter category were included periods of inactivity in 

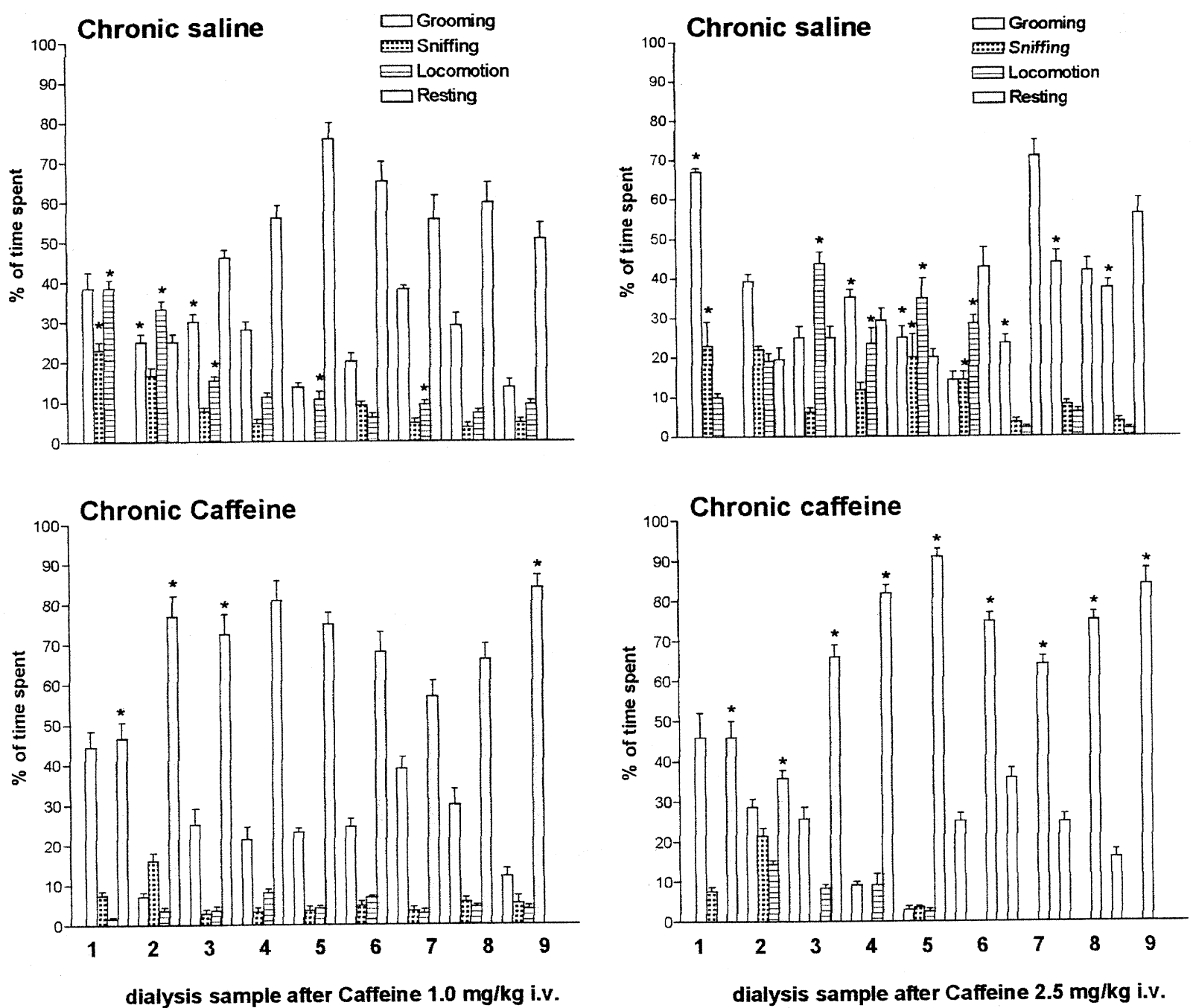

Figure 9. Behavioral effects of caffeine $(1.0 \mathrm{mg} / \mathrm{kg}$ i.v., left, or $2.5 \mathrm{mg} / \mathrm{kg}$ i.v., right) in rats chronically-exposed to saline (upper panels) or caffeine (lower panels). Data obtained from rats given caffeine 1.0 or $2.5 \mathrm{mg} / \mathrm{kg}$ i.v., from which were determined dialysate concentrations of DA or ACh, were pooled. Vertical bars represent S.E.M. ${ }^{*} p<.05$ at Tukey's post-hoc analysis as compared with the identical behavioral item during the corresponding time point of the chronic saline or chronic caffeine group.

which rats were either resting on the bedding or sleeping). The administration of caffeine at the dose of 1.0 $\mathrm{mg} / \mathrm{kg}$ (Figure 9, left) to rats chronically treated with saline produced a pattern of behavioral activation that was significantly different as compared with that produced by caffeine $1.0 \mathrm{mg} / \mathrm{kg}$ given to rats chronically treated with caffeine (2-way ANOVA): Grooming: $\left.\mathrm{F}(\text { treatment })_{1,120}=3.3, \mathrm{~ns}\right)$; Sniffing: $\mathrm{F}(\text { treatment })_{1,123}=$ 25.62, $p<.0001$ and $p<.05$, post hoc test); Locomotion: $\mathrm{F}$ (treatment $)_{1,127}=323.3, p<.0001$ and $p<.05$, post hoc test); and Resting: $\mathrm{F}$ (treatment) $)_{1,129}=206.2, p<.0001$ and $p<.05$, post hoc test). Similarly, the administration of caffeine at the dose of $2.5 \mathrm{mg} / \mathrm{kg}$ (Figure 9, right) to rats chronically treated with saline produced a pattern of behavioral activation that was significantly different as compared with that produced by caffeine $2.5 \mathrm{mg} / \mathrm{kg}$ given to rats chronically treated with caffeine (2-way ANOVA): Grooming: $\mathrm{F}$ (treatment $)_{1,126}=171.9, p<$ .0001 and $p<.05$, post hoc analysis); Sniffing: $\mathrm{F}$ (treatment) $)_{1,110}=162.1, p<.0001$ and $p<.05$, post hoc test); Locomotion $\mathrm{F}$ (treatment) $)_{1,115}=193.3, p<.0001$ and $p<$ .05 , post hoc test); and Resting: $\mathrm{F}$ (treatment) $)_{1,124}=119.5$, $p<.0001$ and $p<.05$, post hoc test). The administration, to drug-naive animals, of caffeine at the doses of $0.25,0.5 \mathrm{mg} / \mathrm{kg}$ i.v. (data not shown), evoked a dosedependent behavioral activation with arousal, sniffing at the air and grooming. DPCPX (data not shown) caused some wet-dog shakes at all doses tested during the first $20 \mathrm{~min}$ after the injection. DPCPX $0.0625 \mathrm{mg} /$ $\mathrm{kg}$ i.v. failed to produce any motor activation, while, in contrast, DPCPX $0.125 \mathrm{mg} / \mathrm{kg}$ i.v. produced sniffing and digging under the bedding and this behavior was 
more pronounced after the dose of $0.25 \mathrm{mg} / \mathrm{kg}$ i.v. SCH 58261(data not shown), similarly to caffeine, produced a dose-dependent behavioral activation with a pattern that varied from sniffing at lower doses $(0.0625$ and $0.125 \mathrm{mg} / \mathrm{kg}$ i.v.), to grooming and locomotion at intermediate doses $(0.25$ and $0.5 \mathrm{mg} / \mathrm{kg}$ i.v.) and stereotyped sniffing at the higher dose $(1 \mathrm{mg} / \mathrm{kg}$ i.v.).

\section{DISCUSSION}

The present study shows that caffeine, given intravenously at doses that elicit behavioral stimulation, increases extracellular DA in the PFCx but not in the NAc shell or core. No changes in dialysate DA were also obtained at intraperitoneal doses of caffeine that have been reported to induce conditioned place-preference (Patkina and Zvartau 1998; Bedginfield et al. 1998). These observations are relevant for the mechanism of the psychostimulant properties of caffeine and for the debated issue of the reinforcing and addictive properties of caffeine. First, the present results exclude that the psychostimulant properties of caffeine are related to stimulation of endogenous DA transmission in the NAc. A previous report of increased striatal DA concentrations by caffeine refers to the local infusion of the drug at concentrations not reached by systemic administration (Okada et al. 1997). It is unlikely that the psychostimulant properties of caffeine are the result of the increase of DA in the PFCX as drugs (antidepressants) known to increase DA in the PFCX but not in the NAc are devoid of psychostimulant properties (Tanda et al. 1996). Rather than of DA release, the psychostimulant properties of caffeine are likely to be the result of blockade of $\mathrm{A}_{2 \mathrm{a}}$ receptors in the striatum including the NAc (Dixon et al. 1996; Palmer and Stiles 1995). Failure to activate DA transmission might be related to the relatively weak reinforcing properties of caffeine. In fact this drug, while inducing place-conditioning (Patkina and Zvartau 1998; Bedginfield et al. 1998), fails to elicit self-administration (Garrett and Griffiths 1998; Griffiths and Mumford 1995; Nehlig 1999). The failure of caffeine to serve as a reinforcer for self-administration behavior, in turn, might be related to its failure to induce dependence according to the criteria of DSM-IIIR and IV (APA 1994). Thus, caffeine, in spite of its ability to induce tolerance and physical dependence, does not consistently induce those behavioral abnormalities typical of addictive drugs and substances (APA 1994). As a result of this, in spite of addictive liability suggestions (Griffiths and Mumford 1995) caffeine is not listed among dependence-producing substances in DSM-IIIR and IV (APA 1994).

As a matter of fact, the failure of caffeine to increase DA in the NAc shell makes it different from drugs with reinforcing and addictive properties, as these drugs share the ability of increasing DA in the NAc shell (Cadoni and Di Chiara 1999, 2000; Pontieri et al. 1995; Pontieri et al. 1996; Tanda et al. 1997). Therefore, the present observations seem consistent with the proposal that the property of increasing DA in the NAc shell is a biochemical expression of the addictive potential of a drug (Di Chiara 1998, 1999).

While ineffective on DA transmission in the NAc, caffeine stimulates DA and ACh transmission in the PFCx. This effect could be related to the psychostimulant properties of caffeine but is unclear if this change is the cause or the effect of these properties. In fact, it has been proposed that adenosine regulates arousal by acting onto the cell bodies of pontine cholinergic projection nuclei (Rainnie et al. 1994; Strecker et al. 2000). These neurons, through their connections with cortically projecting cholinergic neurons (Mesulam et al. 1983; Schwaber et al. 1987) are thought to regulate cortical activity (Sarter and Bruno 2000).

As to the mechanism of the stimulant effects of caffeine on cortical DA and ACh reported here, the observation that they can be reproduced both by DPCPX $\left(\mathrm{A}_{1}\right.$ antagonist) (Bruns et al. 1987) and by SCH $58261\left(\mathrm{~A}_{2 \mathrm{~A}}\right.$ antagonist) (Zocchi et al. 1996), and the circumstance that caffeine is an antagonist at both $\mathrm{A}_{1}$ and $\mathrm{A}_{2 \mathrm{~A}}$ receptors indicates that, at least in principle, both receptors can be responsible for these effects. Thus, combined blockade of $A_{1}$ and $A_{2 A}$ receptors might explain the high in vivo potency of caffeine on DA and ACh transmission compared with its relatively low affinity for each receptor subtype in vitro (Fredholm and Svenningsson 1995).

On the other hand, the finding that DPCPX stimulates cortical $\mathrm{ACh}$ transmission is in agreement with previous in vitro (Broad and Fredholm 1996) and in vivo studies (Carter et al. 1995) showing that adenosine $\mathrm{A}_{1}$ receptors are involved, at multiple sites of action, in the tonic inhibitory action exerted by adenosine on cholinergic neuronal activity (Rainnie et al. 1994).

Blockade of adenosine $A_{2 A}$ receptors by KF 17837 does not affect the inhibition by adenosine of ACh release from rat cortical slices (Broad and Fredholm 1996); conversely, adenosine $\mathrm{A}_{2 \mathrm{~A}}$ receptor agonists, applied locally in the hippocampus, via the dialysis probe, fail to affect caffeine-induced ACh release in the hippocampus (Carter et al. 1995). These findings would suggest that the effects of caffeine and of $\mathrm{A}_{2 \mathrm{~A}}$ antagonists on ACh release in vivo are unrelated to a local intra-cortical action. Therefore extrinsic mechanisms should be envisioned for these effects. An explanation of our results might be provided by the fact that adenosine $\mathrm{A}_{2 \mathrm{~A}}$ receptors co-localize with $D_{2}$ receptors in striato-pallidal neurons where they affect in an opposite manner signal transduction through the cAMP generating system (Ferre et al. 1992; Ongini et al. 1996). Therefore blockade of adenosine $\mathrm{A}_{2 \mathrm{~A}}$ receptors by $\mathrm{SCH} 58261$ 
might shift the $A_{2 A} / D_{2}$ balance in favor of $D_{2}$ receptors in terminal DA areas (Ongini et al. 1996) including the ventral striatum, thus disinhibiting basal forebrain ACh neurons projecting to the cerebral cortex and hippocampus (Mesulam et al. 1983; Schwaber et al. 1987). An alternative explanation of caffeine- and SCH 58261induced ACh release takes into account the fact that cortical and hippocampal ACh release is positively related to changes of the behavioral state from resting to activity as well as following sudden changes in the light-dark phase (Day et al. 1991; Mizuno et al. 1991); thus, behavioral stimulation by SCH 58261 (present study and Ferre et al. 1994) might secondarily enhance cortical ACh release.

However, the observation that chronic exposure to caffeine resulted in tolerance to its locomotor stimulant effects but not to caffeine-induced increases of cortical ACh release is against such interpretation. Caffeineinduced stimulation of DA release in the PFCx did undergo tolerance upon chronic caffeine, consistently with a role of motor activation in the effect of caffeine on PFCx DA release.

In animals tolerant to the locomotor stimulant effects of caffeine, one might ask what is the behavioral correlate of stimulation of $\mathrm{ACh}$ release in the cortex. If one considers that the arousing effects of caffeine are resistant to tolerance, stimulation of ACh release in the cortex might be involved in the EEG desynchronizing effects of caffeine. Further studies are needed to substantiate this suggestion.

\section{ACKNOWLEDGMENTS}

This study was supported by funds from Ministero dell'Istruzione e dell'Università (COFIN - MIUR) and from ASIC (Association for Scientific Information on Coffee), France. Microdialysis membranes (Hospal, Filtral 20) were kindly donated by Hospal, Bologna, Italy. The authors thank Dr. Ennio Ongini and Schering-Plough, Milan, Italy, for generous gift of SCH 58261.

\section{REFERENCES}

Acquas E, Wilson C, Fibiger HC (1996): Conditioned and unconditioned stimuli increase frontal cortical and hippocampal acetylcholine release: effects of novelty, habituation, and fear. J Neurosci 16:3089-3096

APA (1994): Diagnostic and Statistical of Mental Disorders. 4th ed. Washington, D.C., USA, APA

Bedginfield JB, King DA, Holloway FA (1998): Cocaine and caffeine: conditioned place preference, locomotor activity, and addictivity. Pharmacol Biochem Behav 61:291-296

Broad RM, Fredholm BB (1996): A1, but not A2A, adenosine receptors modulate electrically stimulated [14C]acetylcholine release from rat cortex. J Pharmacol Exp Ther 277:193-197
Bruns RF, Fergus JH, Badger EW, Bristol JA, Santay LA, Hartman JD, Hays SJ, Huang CC (1987): Binding of the A1-selective adenosine antagonist 8-cyclopentyl-1,3dipropylxanthine to rat brain membranes. Naunyn Schmiedebergs Arch Pharmacol 335:59-63

Cadoni C, Di Chiara G (1999): Reciprocal changes in dopamine responsiveness in the nucleus accumbens shell and core and in the dorsal caudate-putamen in rats sensitized to morphine. Neuroscience 90:447-455

Cadoni C, Di Chiara G (2000): Differential changes in accumbens shell and core dopamine in behavioral sensitization to nicotine. Eur J Pharmacol 387:R23-R25

Carter AJ, O'Connor WT, Carter MJ, Ungerstedt U (1995): Caffeine enhances acetylcholine release in the hippocampus in vivo by a selective interaction with adenosine A1 receptors. J Pharmacol Exp Ther 273:637-642

Chou DT, Khan S, Forde J, Hirsh KR (1985): Caffeine tolerance: behavioral, electrophysiological and neurochemical evidence. Life Sci 36:2347-2358

Crane AM, Porrino LJ (1989): Adaptation of the quantitative 2-[14C]deoxyglucose method for use in freely moving rats. Brain Res 499:87-92

Damsma G, Westerink BH, de Vries JB, Van den Berg CJ, Horn AS (1987): Measurement of acetylcholine release in freely moving rats by means of automated intracerebral dialysis. J Neurochem 48:1523-1528

Day J, Damsma G, Fibiger HC (1991): Cholinergic activity in the rat hippocampus, cortex and striatum correlates with locomotor activity: an in vivo microdialysis study. Pharmacol Biochem Behav 38:723-729

Di Chiara G (1998): A motivational learning hypothesis of the role of mesolimbic dopamine in compulsive drug use. J Psychopharmacol 12:54-67

Di Chiara G (1999): Drug addiction as dopamine-dependent associative learning disorder. Eur J Pharmacol 375:13-30

Dixon AK, Gubitz AK, Sirinathsinghji DJ, Richardson PJ, Freeman TC (1996): Tissue distribution of adenosine receptor mRNAs in the rat. Br J Pharmacol 118:14611468

Ferre S, Fuxe K, von Euler G, Johansson B, Fredholm BB (1992): Adenosine-dopamine interactions in the brain. Neuroscience 51:501-512

Ferre S, O'Connor WT, Snaprud P, Ungerstedt U, Fuxe K (1994): Antagonistic interaction between adenosine $\mathrm{A} 2 \mathrm{~A}$ receptors and dopamine D2 receptors in the ventral striopallidal system. Implications for the treatment of schizophrenia. Neuroscience 63:765-773

Fibiger HC (1991): Cholinergic mechanisms in learning, memory and dementia: a review of recent evidence. Trends Neurosci 14:220-223

Fredholm BB, Svenningsson P (1995): Striatal adenosine $\mathrm{A} 2 \mathrm{~A}$ receptors - where are they? What do they do? Trends Neurosci 19:46-47

Fredholm BB, Battig K, Holmen J, Nehlig A, Zvartau EE (1999): Actions of caffeine in the brain with special reference to factors that contribute to its widespread use. Pharmacol Rev 51: 83-133

Garrett BE, Griffiths RR (1998): Physical dependence increases the relative reinforcing effects of caffeine versus placebo. Psychopharmacology (Berl) 139:195-202 
Griffiths RR, Mumford GK (1995): Caffeine - A drug of abuse? In: Bloom FE, Kupfer DJ. (eds), Psychopharmacology: The fourth generation of progress, New York, Raven Press, pp 1699-1713

Heimer L, Zahm DS, Churchill L, Kalivas PW, Wohltmann C (1991): Specificity in the projection patterns of accumbal core and shell in the rat. Neuroscience 41:89-125

Heimer L, Alheid GF (1991): Piecing together the puzzle of basal forebrain anatomy. Adv Exp Med Biol 295:1-42

Lee KS, Reddington M (1986): Autoradiographic evidence for multiple CNS binding sites for adenosine derivatives. Neuroscience 19:535-549

Mesulam MM, Mufson EJ, Wainer BH, Levey AI (1983): Central cholinergic pathways in the rat: an overview based on an alternative nomenclature (Ch 1-Ch6 ). Neuroscience 10:1185-1201

Mizuno T, Endo Y, Arita J, Kimura F (1991): Acetylcholine release in the rat hippocampus as measured by the microdialysis method correlates with motor activity and exhibits a diurnal variation. Neuroscience 44:607-612

Moore H, Sarter M, Bruno JP (1993): Bidirectional modulation of stimulated cortical acetylcholine release by benzodiazepine receptor ligands. Brain Res 627:267-274

Nehlig A (1999): Are we dependent upon coffee and caffeine? A review on human and animal data. Neurosci Biobehav Rev 23:563-576

Okada M, Kiryu K, Kawata Y, Mizuno K, Wada K, Tasaki H, Kaneko S (1997): Determination of the effects of caffeine and carbamazepine on striatal dopamine release by in vivo microdialysis. Eur J Pharmacol 321:181-188

Ongini E, Dionisiotti S, Morelli M, Ferre S, Svenningsson P, Fuxe K, Fredholm BB (1996): Neuropharmacology of the adenosine A2A receptors. Drug Development Research 39:450-460

Palmer TM, Stiles GL (1995): Adenosine receptors. Neuropharmacology 34:683-694

Passetti F, Dalley JW, O'Connell MT, Everitt BJ, Robbins TW (2000): Increased acetylcholine release in the rat medial prefrontal cortex during performance of a visual attentional task. Eur J Neurosci 12:3051-3058

Patkina NA, Zvartau EE (1998): Caffeine place conditioning in rats: comparison with cocaine and ethanol. Eur. J. Neuropsychopharmacol. 8:287-291

Paxinos G, Watson C (1998): The rat brain in stereotaxic coordinates. Sydney, Academic Press

Pontieri FE, Tanda G, Di Chiara G (1995): Intravenous cocaine, morphine, and amphetamine preferentially increase extracellular dopamine in the "shell" as com- pared with the "core" of the rat nucleus accumbens. Proc Natl Acad Sci USA 92:12304-12308

Pontieri FE, Tanda G, Orzi F, Di Chiara G (1996): Effects of nicotine on the nucleus accumbens and similarity to those of addictive drugs. Nature 382:255-257

Porkka-Heiskanen T, Strecker RE, Thakkar M, Bjorkum AA, Greene RW, McCarley RW (1997): Adenosine: a mediator of the sleep-inducing effects of prolonged wakefulness. Science 276:1265-1268

Portas CM, Thakkar M, Rainnie DG, Greene RW, McCarley RW (1997): Role of adenosine in behavioral state modulation: a microdialysis study in the freely moving cat. Neuroscience 79:225-235

Rainnie DG, Grunze HC, McCarley RW, Greene RW (1994): Adenosine inhibition of mesopontine cholinergic neurons: implications for EEG arousal. Science 263:689-692

Sarter M, Bruno JP (2000): Cortical cholinergic inputs mediating arousal, attentional processing and dreaming: differential afferent regulation of the basal forebrain by telencephalic and brainstem afferents. Neuroscience 95:933-952

Schwaber JS, Rogers WT, Satoh K, Fibiger HC (1987): Distribution and organization of cholinergic neurons in the rat forebrain demonstrated by computer-aided data acquisition and three-dimensional reconstruction. J Comp Neurol 263:309-325

Strecker RE, Morairty S, Thakkar MM, Porkka-Heiskanen T, Basheer R, Dauphin LJ, Rainnie DG, Portas CM, Greene RW, McCarley RW (2000): Adenosinergic modulation of basal forebrain and preoptic/anterior hypothalamic neuronal activity in the control of behavioral state. Behav Brain Res 115:183-204

Svenningsson P, Nomikos GG, Fredholm BB (1999): The stimulatory action and the development of tolerance to caffeine is associated with alterations in gene expression in specific brain regions. J Neurosci 19:4011-4022

Tanda G, Bassareo V, Di Chiara G (1996): Mianserin markedly and selectively increases extracellular dopamine in the prefrontal cortex as compared to the nucleus accumbens of the rat. Psychopharmacology (Berl) 123: 127-130

Tanda G, Pontieri FE, Di Chiara G (1997): Cannabinoid and heroin activation of mesolimbic dopamine transmission by a common mu1 opioid receptor mechanism. Science 276:2048-2050

Zocchi C, Ongini E, Conti A, Monopoli A, Negretti A, Baraldi PG, Dionisotti S (1996): The non-xanthine heterocyclic compound SCH 58261 is a new potent and selective A2a adenosine receptor antagonist. J Pharmacol Exp Ther 276:398-404 